\title{
An Investigation into Omani Physical Education Teachers' Beliefs about Physical Education Teachers' Characteristics and their Roles in Omani Schools \\ Nasser Yasser Al-Rawahi \\ Sultan Qaboos University \\ nrawahi@squ.edu.om
}

Submitted: ${ }^{\top} \backslash \backslash 2010$

Reviewed: $2\lceil\backslash \wedge 2011$

Accepted: $12 \backslash 2 \backslash 2011$

The purpose of this study was to investigate Omani physical education teachers' (pre-service and in-service) beliefs about the characteristics and roles of physical education teachers in Omani schools. Interviews were used to achieve this purpose by interviewing 29 participants: 12 student teachers and 17 teachers. Data were analysed qualitatively by using analytic induction and interpretive analytic framework. Qualitative results show that student teachers and teachers have similar beliefs about the general and professional characteristics of a physical education teacher. Between $70 \%$ and $95 \%$ of participants believed that the essential general characteristics of physical education teachers are: having a strong personality, being an ideal model for students, having patience and tolerance, and communicating effectively with students. Also, similar beliefs were found among the participants regarding the professional characteristics. They believed that a successful physical education teacher is one who has conviction about his profession, and who is always physically fit in order to be able to manage all of the profession's requirements in or out of school. Results also indicated that student teachers believed in traditional roles of the teacher who is more concerned about giving knowledge to students, while experienced teachers believe in progressive teaching roles of the teacher who facilitates students' learning. All the results are discussed in relation to the physical education context in Oman.

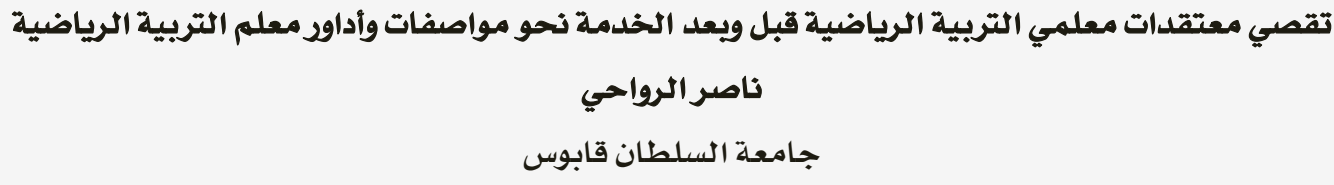

هدفت الدراسة الحالية إلى تقصي معتقدات معلمي التربية الرياضية قبل وبعد الخدمـة نحو مواصفات وأداور معلهم التربية الرياضية. استخدم الباحث المنهج النوعي عن طريق تطبيق المقابلة كأداة لجمـع المعلومات والبيانات اللازمـة. تكونت عينة الدراسة التي تمت مقابلتها من إثنى عشر طالبـا وطالبة معلمة، وسبعة عشر معلما ومعلمهة للرياضـة المدرسية. خلصت الدراسـة إلى أهم النتائج التتالية :

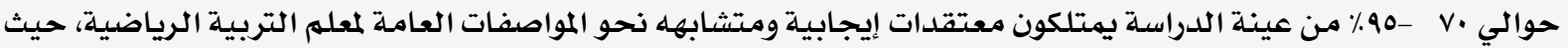
أشاروا إلى أن من أهم المواصفات العامة لمعلم التربية الرياضية تتمثل ِِ امتلاكه الشخصية القوية،والقدوة المثالية لطلابه،و يهتلك الصبر والتحمل الكلازم للعمل التدريسي،ولديه القدرة على الاتصال الفعال مـع طلابه. وجود معتقدات إيجابية ومتشابه أيضا نحو مواصفات معلهم التربية الرياضيـة التخصصيـة، حيث أشـارت عينـة الدراسـة إلى أن أهم المواصفات الخاصـة بتخصص التربية الرياضيلة التي يجب أن يمتلكها المعلم تتمثل ِِّوجود القناعة التامـة بالتخصص، وامتلاك اللياقة البدنية الكافية للعمل داخل وخارج المدرسة. اختلفت عينة الدراسة ِِّ معتقداتها نحو أدوار معلهم التربية الرياضية، حيث أظهرت النتائج أن الطلبة المعملين أكثر اعتقادا بالأدوار التقليدية للمعلم مثل نقل المعرفة للطلاب، بينما تعتقد عينة الدراسـة من المعلمـين بـالأدوار الحديثة للمعلهم كدوره فِّ تسهيل وإرشـاد الطلبـة نحو التعلهم. 


\section{Introduction}

There is growing research highlighting the importance of studying teachers' beliefs about different aspects of the teaching and learning process in different educational contexts. Researchers (e.g. Pajares, 1992; Kagan, 1992; Tsangaridou, 2006; Irez, 2007) have asserted that understanding teachers' beliefs can inform educational practice in a way that other research agenda have not provided. This view is based on the assumption that teachers' thoughts and beliefs are the best indicators of the decisions made by teachers throughout their teaching practice. Kagan (1992) has stated that the study of beliefs is significant to educational practice, that beliefs may be "the clearest measure of a teacher's professional growth", and that understanding them is "instrumental in determining the quality of interaction one finds among teachers in a given school" ( $\mathrm{p}$. 85). Rovegno (2003) suggests that "to understand good teaching, we need to hear teachers' voices and study what good teachers thought, knew, and believed" (p. 295).

The role of beliefs in improving the teaching and learning process has been discussed by many researchers (e.g. Pajares, 1992; Fang, 1996; Richardson, 1996, Tsangaridou, 2006). Nespor (1987) argued that, to understand teaching from teachers' perspectives, we have to understand the beliefs with which they define their work. This view is further supported by O'Sullivan (2003), who argues that, to improve the quality of teacher education programmes, teacher educators need to understand the crucial role of teachers' beliefs and address them in their programmes in order to develop teachers' views about teaching and learning.

However, in spite of the fact that beliefs play such an important role, they have not received much attention from researchers in the context of general education as well as physical education (Tsangaridou, 2006). Very little attention has been paid to teachers' personal views and the ways they conceptualize their characteristics and their roles in teaching and learning physical education.

Empirical studies in different content areas have suggested the notion of 'image' to expose the personal beliefs teachers have about themselves, about the correct ways of teaching, about the roles of teachers, and about how lessons should be implemented (Connelly and Clandinin, 1988; Johnson, 1994; Calderhead and Robson, 1991). For instance, Capel (2004) argues that, to develop effective physical education teachers, we need to understand their images about themselves, their values, attitudes, and beliefs, and suggests that physical education teachers should be able to reflect on how beliefs, values and attitudes influence what they are doing and, therefore, how these components impact on students' learning. Teachers' beliefs about themselves play a crucial role in determining their relationships with students, their use of classroom management techniques, and the teaching strategies they use in their daily teaching practice.

A review of the literature related to teachers' beliefs about their role shows that teacher-centred and student-centred approaches are the most commonly used methods that teachers use in their actual classroom teaching practice. Simmons et al. (1999) suggest that teachers who prefer the teacher-centred approach view themselves as the only ones who have the responsibility to transmit, organize and deliver the content knowledge; rarely do they allow students to generate questions or procedures. They permit few interactions between students and use a limited repertoire of teaching strategies. On the contrary, teachers who prefer a student-centred approach play the role of a facilitator. They organize activities for students to gain experiences that will lead to the enhancement of the learning process. They also use alternative teaching strategies and forms of assessment. 
Teachers are assumed to play a variety of roles in creating an effective teaching and learning environment. Petterson et al (2004) provide a list of key roles that teachers should play in the classroom: having a good relationship with students; facilitating learning; being a manager, an initiator, a reflection partner, a mentor, and administrator of teaching materials. Aligned with these roles, Aydin et al (2010) found that roles of facilitator, guide, autonomy supporter, authoritarian, and encourager were the dominant roles among Turkish mathematics teachers. Cakmak (2010) at Gazi University in Ankara found that prospective teachers believed in different teacher's roles, such as knowing individual differences, being a supervisor, a good listener, a leader, and having the ability to identify students' weaknesses.

Studies conducted in physical education have paid little attention to the common characteristics and the roles of physical education teachers. In one study, Fung and Chow (2002) tried to identify the dominant teachers' role and classroom practices of student teachers enrolled in a teacher preparation programme for secondary school teaching in Hong Kong. The responses to their questionnaire revealed that the dominant teacher's role, according to the participants, was that of 'nurturing', whereas the dominant set of actual classroom practices was a blend of the 'Apprenticeship' and 'Transmission' approaches. The study also revealed that the participants view themselves as facilitators of learning and as friends of their students. Fung and Chow concluded that better understanding of teachers' beliefs about their roles can have a significant impact on their teaching practices. However, there are few qualitative investigations that have taken into account the beliefs of teachers about their roles in teaching physical education. According to the few studies which have been conducted to understand physical education teachers' beliefs about their characteristics as teachers and their roles in teaching, teachers believe that a good physical education teacher is one who is physically fit, has a good knowledge base, uses a variety of teaching approaches, and is able to perform different activities (Matanin and Collier, 2003; Raudensky et al. 2000). The present study focused on the beliefs that Omani physical education teachers held about their roles as teachers in teaching and the common characteristics of a physical education teacher.

\section{Statement of the study problem}

The Omani government has paid significant attention to the design of wellplanned physical education programmes in an attempt to increase the quality of physical education in Omani schools. Changes have been introduced in the curriculum - syllabus, objectives and teaching materials - in order to improve the quality of physical education( Nathmi, (2005). However, despite the numerous attempts and the enormous efforts devoted to improve the quality of physical education in Oman, limited research has been conducted to investigate the importance of the teachers' voices, and what beliefs they hold about teaching and learning in physical education. From personal experience as a supervisor of teacher trainees, the researcher has found that most pre-service teachers and inservice teachers in Oman hold negative beliefs about different aspects of teaching and learning in physical education. This may be related to the existing mismatch between the official requirements stated by policy makers and the teachers' own beliefs. Therefore, this study is an attempt to consider Omani physical education teachers' voices and their views on the characteristics and roles of physical education teachers in Omani schools.

\section{Purpose of study}

The purpose of the study is to offer a comprehensive understanding of how the participants interpret, understand, and constitute their beliefs about the characteristics and roles of physical education teachers. The study aims to answer the following research question: 
What beliefs do Omani student teachers (pre-service) and teachers (in-service) hold about the characteristics and roles of physical education teachers? Methodology

To answer the research question mentioned above, the qualitative method was felt to be an appropriate method for the current study. Knowledge from the interpretive or qualitative perspective is something that a researcher extracts from those being studied by using an interactive process like the interview method (Crotty, 2003; Flick, 2006). Therefore, data on teachers' beliefs about the characteristics and roles of physical education teachers was obtained through a dialogue between the participants (student teachers and teachers) and the researcher.

Further, justifications for adopting the qualitative approach in the current study are as follows. First, studying teachers' beliefs about the characteristics and roles of physical education teachers is a new study which has not been undertaken yet in Oman. Marshall and Rossman (2006) and Creswell (1994) claim that the interpretive approach can be very useful in new areas of research. Secondly, this study starts without any theoretical assumptions and did not aim to test any hypothesis but relies on what can be inferred from its subjects and understanding of participants' beliefs through induction, which is viewed as one of the most prominent characteristics of the qualitative approach, in which the process starts with data collection and ends with the formulation of a theory (Merriam, 1998). Finally, the researcher is himself the primary instrument of data collection from the field. In the qualitative approach, data are mediated through the researcher rather than through other mediators such as machines (Dey, 1993).

\section{Population and Sample}

Two types of population included in this study. The first one included of all inservice physical education teachers work in different primary, preparatory, and basic education schools including urban, suburban, and rural areas, in tow educational regions, Muscat and ALDakhliyah $(\mathrm{N}=143)($ Ministry of education, 2006). The second population included sixty eight student teachers who were attending teaching practicum experience during academic year 2007/2008. The sample size comprised of twelve student teachers ( 8 male and 4 female), and seventeen teachers (12 male and 5 female). The sample size is considered acceptable and meeting the minimum required sample size in qualitative study (Liamputtong \& Ezzy, 2006). All participants were interviewed once at their convenient time and place during their teaching practice or teaching days.

\section{Data collection}

Semi-structured interviews were conducted to understand participants' thinking and perceptions about the characteristics and the roles of physical education teachers. As affirmed by Merriam (1998, 72) "interviewing is necessary when we cannot observe behaviours, feelings, or how people interpret the world around them". Using semi-structured interviews provides the perspectives of the interviewees and helps generate hypotheses from such perspectives (Vulliamy, 1990), and understand what the participants think is important in their own situation (Radnor, 2001).

All interviews in this study were conducted in convenient settings. For the teachers, interviews were conducted in the schools where they were teaching. Student teachers were interviewed at the University or at the schools during their teaching practice days. Each interview lasted approximately 35-45 minutes, and was recorded on audio tape, followed by a verbatim transcription.

Trustworthiness and credibility were achieved by applying Merriam's 
(1998) strategies to ensure internal validity: triangulation, member checks, and peer examination. Member checks occurred throughout the study between the participants and the researcher to make sure (a) that the data accurately expressed what they believed, and (b) that the interpretations were presented accurately. Peer examination between two colleagues and the researcher was done to ensure that the findings of the study were presented systematically and logically.

To avoid misinterpretation of the language, and because the study was being conducted in an Arabic context, the interview schedule and information obtained from the interviews were translated into English and Arabic. The translations were subsequently given to three professional lecturers at the English department to check the accuracy of translation and ease of understanding. Modifications were made based on their comments, leading to the final version.

\section{Data analysis}

Qualitative data of the current study were analyzed using analytic induction and interpretive analytic framework. The analysis and data interpretation processes which were followed in this study were based on Merriam's (1998) approaches for analyzing and managing qualitative data, combined with the analytical stages of the grounded theory approach.

The first step was to analyze the data of the current study started by management data process. The qualitative researcher should start with coding the data in a way that makes it easy to access any information that might be needed later (Merriam, 1998). Therefore, files were created containing basic information on each participant, labelled with pseudonyms, teaching experiences and all data gathered from interviews regarding their beliefs about the characteristics and roles of physical education teachers. These files helped to sort out and reduce the data to a manageable size and provided the researcher with an important starting point for analyzing emerging patterns and relationships (Strauss and Corbin, 1998).

After the completion of the management step, the analytical stages of the grounded theory approach were followed. During the first stage, i.e. open coding, data is broken down into concepts (distinct ideas, events, or actions) and then labelled by these concepts and grouped into categories. The data sorted into the folders mentioned above was categorized under a given label. At this point, lists of categories were created from each interview, and compared with the list of categories created from other individuals' interviews in the same sample type. For example, the list of categories and subcategories of the first student teacher's beliefs about the characteristics and roles of physical education teachers was compared with the list from other student teachers and teachers. After the completion of this step, a synthesis of the similarities and differences of beliefs of the participants in each sample group (student teachers and teachers) was made in separate folders. This synthesis worked as a primary source to make comparisons between the two main samples of this study.

Following this was the axial coding stage. The categories and subcategories listed and identified in the previous stage were re-examined to determine how they linked together, in order to facilitate the explanation of the phenomena being studied. This stage included editing, validating, adding or deleting some ideas thought to be necessary for making the result more logical and comprehensive. In the final stage, the display data, the beliefs of Omani physical education student teachers and teachers about the characteristics and roles of physical education teachers were presented. They were presented with the addition of the total percentage for each characteristic or role for facilitating readers' understanding of how many times each characteristic and role were mentioned by the study 
participants (See the result section for more details). The results presented in the following section are assumed to present the actual beliefs and thoughts that samples held about the characteristics and roles of physical education teachers in the Omani context.

\section{Results}

The following sections explore how student teachers and teachers perceive the characteristics and roles of Omani physical education teachers. The results generated from interviews with the participants of the study which regard to their beliefs about the characteristics of physical education teachers are classified into two main categories, namely general and professional characteristics.

\section{General characteristics of physical education teachers}

The common theme that emerged from the interviews and which was agreed upon by eleven student teachers (91\%) and sixteen teachers (94\%) was that a physical education teacher should have a strong personality. Ahmed, a student teacher, described a physical education teacher as follows: "Firstly, a physical education teacher should have a strong personality.... he should deal in school with more than 1000 students and if he does not have a strong personality... he will fail to manage students properly"

The teacher also is expected to be a proper role model for students in and outside the school. More than $80 \%$ of participants believed that the physical education teacher should be the one who students can learn from about the moral behaviour and educational skills. Fysal mentioned this, saying: "The Physical Education teacher should be a model for students... in terms of the way of demonstrating sport skills... in terms of the moral dimension of behaviour... in terms of subject knowledge of sport."

Other common characteristics believed to be important by many Omani student teachers and teachers were patience and tolerance, needed when working with students who have various needs and interests. Salwa commented on these virtues by saying: "A physical education teacher should have general and specific characteristics. For example, he should be patient and tolerant, because for me as a physical education teacher with first levels... Students in these levels are moving a lot... so, I should be patient with them."

A further common characteristic agreed upon by $75 \%$ of student teachers and $70 \%$ of teachers was that teachers should have the ability to communicate effectively with students. Mohammed, a student teacher, commented that "The successful physical education teacher is the one who listen to students and is always alongside with them. Students like a teacher who deal with them as friends and understands their needs".

$52 \%$ of the experienced teachers added another dimension to the virtue of successful communication. They believed that the successful teacher is one who does not communicate solely with students in school, but with society as well. Rabah described this point well: "It is important for you as PE teacher to involve with society outside the school... participate in activities with different groups and institutions, because this involvement helps you to get any help from them when you need it. For example, many times I used to borrow equipment for school from the clubs in society."

Cooperation with administration and teachers in school was also believed by seven teachers to be an essential feature that a successful physical education teacher should have. In this regard, Hasan commented: "In order to be successful in your job... you should cooperate with your colleagues and administration staff in school. Without cooperation no one can do his job alone especially in physical education."

\section{Professional characteristics of physical education teachers}


Physical education requires teachers to hold specific and exclusive virtues and characteristics. The most common belief regarding this, held by $91 \%$ of Omani student teachers and 100\% of teachers, was that teachers should have job confidence. They believe that to be a successful teacher in physical education, one must love it and have conviction to teach physical education. These characteristics are believed to lead to positive attitudes towards physical education. All these features were viewed by both groups as distinctive characteristics of the physical education teacher. The following statement supports this: "I think, firstly, a teacher should have an intrinsic conviction that he wants to become a teacher in the field of PE. This is the first step."

To illustrate the importance of this belief, Fatima said: "if I have conviction of what I do... I will be able to manage my class perfectly... I will be able give students new things... I will be able to teach skills in the right way. I will do my job without frustration. I will work under any condition because I love my job."

Working within the physical education setting requires teachers to have the energy and ability to fulfil all school and teaching requirements successfully. Thus, all the student teachers and fifteen teachers believe that the physical education teacher should be physically fit in order to carry out his job efficiently. The following statement made by Salem supports this: "It is important as a PE teacher to be physically fit in order to practice different skills to different classes successfully."

In addition to being physically fit, leadership was believed to be an essential virtue that characterises physical education teachers. Seventy-five per cent of student teachers and eighty-two per cent of teachers agreed that successful physical education teachers should have leadership characteristics. Yasser mentioned this point by saying: "As a PE teacher... if you don't able to manage your students properly ... you feel that students don't follow your commands... They don't care what you are asking them to do... So, the leader teacher... encourages students to value physical education as a subject."

In addition to the characteristics mentioned above, there are certain professional features which describe the physical education teacher. The teachers who participated in the study believe that another important characteristic of the physical education teacher is to have theoretical and practical knowledge of different sport skills. In addition, teachers should have cultural knowledge of various sports and rules. Hasan commented on this point:

"In order to be a successful teacher... You should know everything in your subject, not only the practical ways of doing skills but also the theoretical ones....For example if you teach a student a difficult skill... You need to know how to do it and you should also have background information of it in terms of the technical ways... its rules and so on."

A further professional characteristic mentioned by thirteen teachers was that physical education teachers should update their knowledge by reading and being aware of the recent changes and developments regarding their subjects. Their readiness and willingness to read is believed to be helpful in improving teaching and learning physical education. Raya, a teacher, said: "One of the characteristics of the physical education teacher is reading a lot of books, knowing what new things have been discovered in his subject. Because this definitely will help him to enhance his teaching and student learning as well."

\section{The role of the physical education teacher}

The physical education teacher, like other teachers, is expected to play significant roles in the teaching and learning process, starting from lesson planning, providing instructional tasks, and observing and enhancing students' learning process. The data collected regarding the role of the physical 
education teacher were classified into two main categories, the "traditional teaching role" and the "progressive teaching role".

\section{Traditional teaching roles}

As mentioned above, the qualitative results of the study reveal that the majority of student teachers held views reflecting the traditional teaching roles. Data revealed that more than $50 \%$ of student teacher participants believed that one of the most important roles of a physical education teacher is transmitting knowledge. They considered that the physical education teacher is responsible for planning teaching tasks and ensuring that students acquire

all planned information through lesson plans. Nasser, a student teacher, described his role as follows: "My duty in classroom is to make sure that students know every thing that I want them to know."

Another traditional role believed to be important by eight student teachers $(66 \%)$ and only three teachers $(17 \%)$ was that the physical education teacher should make sure that students in the classroom achieved a high level of performance in various sport skills. Regarding this role, Kalfan said: "The important thing to me in the classroom is that students apply the target skills perfectly."

It is also apparent that roles such as controller and manager were believed by many student teachers and a few teachers to be dominant teaching roles. More than half of student teachers and a few teachers believed that the successful teacher is one who can manage students in the classroom successfully, and who acts as a leader for all instructional missions in the teaching and learning process. One example of this belief was given by Fahad: "Our job is to teach students skills and manage them in the classroom because if they feel you give them a chance to do what they do... you will lose your control... and you will find the class... I can say as a 'fish market'." Similarly, Ramah said: "Classroom management is very important. I think any teachers must have a good control over the class itself so that they can teach without any disturbance".

Some participants also believed that one of the roles of a physical education teacher is to provide feedback to students' mistakes directly. Nora commented on this role as follows: "I believe that a good teacher should be able to interfere when any mistakes happen in the classroom either when students learn skills or whatever it is. Without that, I will lose my control."

\section{Progressive teaching roles}

The results show that experience in teaching has led the teachers in this study to believe in the usefulness of what can be described as progressive teaching roles of the physical education teacher. Fourteen experienced teachers and six student teachers in this study believed that one of the main roles of the physical education teacher is to develop student talents in various sport skills. They considered that students have natural talents in different sporting activities and teachers should develop these talents. One teacher, Yasser, commented on this: "In fact, our job in the PE lesson is to develop student talents in sport that they like... Whether it is football... basketball... handball. Because most students have basic knowledge on how to do some sport skills particularly those students who join clubs in society... so, we should do is just develop their abilities".

Another progressive teaching role mentioned by $23 \%$ of student teachers and $64 \%$ of teachers was that physical education teachers should be able to demonstrate various learning skills with students. They believed that a teacher is a live model for students and in order to teach perfectly, and to gain respect and good response from students, they should be sufficiently prepared in advance to perform the target skills themselves. The following comment was made by Bader: "Our responsibility in class to show students how they can do the teaching skills... if you are 
not able to do that... I think your role in teaching will be useless".

Nine experienced teachers (52\%) believed that it was important for a physical education teacher to act as a facilitator. They believed that the teacher is expected to help students expand their knowledge by themselves, rather than adopting a teacher-centred approach. Teachers also believed that it was best to help students correct their mistakes by themselves and give them the right feedback when it is necessary. Bader, a physical education teacher, addressed this point: "We as PE teachers should try our best to give students opportunities to think for different ways to practice the intended learning skills... and should work as assistants to help them improve their skills and give them the right answers for any problems they face in their attempts to learn sporting skills." Another example was mentioned by Fysal: "We as a teacher should play the role of supervisor in class... we observe students... give them feedback rather than give them every thing... we should try to give them a role in class... we can divide them into groups and assign a leader for each group... the leader should work as assistant teacher... and carry out supervision matters such as giving feedback and praising students' achievement."

In addition, more than a third of experienced teachers and only four student teachers believed that the physical education teacher should be an advisor and a supervisor for students' social, emotional, or cultural needs. Also, roles such as motivator and being a friend to students can be included in the role of advisor, since the teacher, while listening to students' problems, plays these roles at the same time. Regarding this belief, Fysel said: "The physical education teacher is the heart of school... and although there is a social advisor in school... most students, when they have a problem, whatever it is, go to the physical education teacher... Because he is the most loved teacher in school."

Besides the roles mentioned above, the physical education teacher has been viewed as playing a significant role in society. Ten of the participating teachers $(58 \%)$ believed that the successful physical education teacher is one who strives to change the negative attitudes in Omani society towards physical education. According to their views, this mission can be achieved by effective communication with the world outside the school. Raya indicated this point by saying: "We are in society which still does not care about physical education... Society believes that physical education is not important... So, we should try to change these views."

\section{Discussion}

The interviews played a vital role in providing key significant findings in terms of the characteristics and the role of the physical education teacher. The participants mentioned several significant characteristics and roles that were not addressed in the existing literature. In terms of the significant characteristics of physical education teachers, between $80 \%$ and $92 \%$ of student teachers, and between $80 \%$ and $95 \%$ of teachers believed that the essential characteristics of physical education teachers are: having a strong personality, being an ideal model for their students, and holding the virtues of patience and tolerance. Also, between 91\% and $100 \%$ of student teachers, and between $88 \%$ and $100 \%$ of teachers believed that the distinctive professional characteristics of a physical education teacher are: being physically fit and having conviction about the work. All of these characteristics seem to be more important than others for Omani physical education teachers. This might be attributed to the awareness of the participants about the negative beliefs held by many people towards the physical education profession. Many people in Oman do not consider working as a physical education teacher as a profession similar to that of teachers of other subjects. They view the physical education teacher as a teacher for "fun" or "play". These views certainly have an effect, at least emotionally, on teachers' willingness to enter the world of teaching in physical education. Thus, to be a physical education teacher in a society which does 
not value physical education, it is necessary to have a strong personality and conviction about one's job. These characteristics will help teachers confront any "depressed beliefs" and also prove to others that working as a physical education teacher is not different from working as a teacher in other subjects.

Another key finding about the characteristics of physical education teachers obtained from the interviews was that $58 \%$ of the student teachers and $64 \%$ of the teachers believed that one of the main characteristics of physical education teachers is careful planning for physical education lessons. Planning for physical education lessons seems to be a very important aspect for participants, as it helps teachers to remember lesson stages, retrieve associated skills exercises, and avoid unplanned teaching. This finding coincides with Brickhouse's assertion that planning is very important for teachers, because it forms an ideal base for analysing views and practices (Brickhouse, 1993).

Concerning teachers' beliefs about their roles, the majority of student teachers believed in the traditional roles of the teacher as one who conveys knowledge, controls students, and manages all teaching tasks. On the other hand, the results indicated that the majority of experienced teachers expressed roles which represent the progressive roles of developer, advisor, facilitator, motivator, and modifier of negative beliefs about physical education. Similar roles were reported in the studies of Petterson et al. (2004), Aydin (2010) and Cakmak (2010). The disagreement between student teachers and teachers in this study can be attributed to experience. The teacher participants have had more experience in teaching than the student teachers, giving them opportunities to experience and evaluate the various roles that need to be held by physical education teachers.
As mentioned above, one of the most important roles expressed by the experienced teachers was that of modifier of negative beliefs about physical education. Experienced teachers, as proved in qualitative data, have experienced negative beliefs towards physical education either from students in their schools or from the wider society outside the school. Thus, it seems that they emphasised the role of teacher as modifier, because they expect themselves to play a crucial role in modifying and changing some of the negative beliefs towards physical education.

\section{Conclusion}

The results of this study proved that the successful implementation of physical education programmes cannot be achieved without consideration of teachers' beliefs, which should be the first step in designing and innovating school programmes. The results have validated Richardson's (1996) and many other researchers' (e.g. Pajares, 1992; Nespor, 1987; Doolittle et al, 1993; Tsangaridou, 2006) arguments that beliefs are an important concept in understanding teachers' thought processes, classroom practices, and learning to teach. The Omani government has introduced comprehensive changes in school subjects, including physical education. For physical education, new learning objectives have been outlined, new curriculum content designed, new teaching methods advised, and new assessment approaches recommended to meet the needs of the students and the country in the 21st century. The innovations or plans for the improvement of physical education programmes should accommodate, and be consistent with, the potentialities of the society for which it is intended. These innovations must be based on understanding physical education teachers' beliefs about different teaching and learning aspects including their characteristics and their roles in teaching. 
The use of interviews for data collection has proven to be advantageous in exploring teachers' beliefs. The data that was generated from the interviews provided a good understanding of how Omani physical education teachers perceive different characteristics and roles of physical education teachers. It would not have been possible to obtain such a rich and deep understanding by using only a questionnaire, due to the limitations of the tool for participants to express their views frankly. The adoption of the interview method implies a need for using this method in future to gain insights about different aspects of teaching and learning processes. Also, further research methods, such as questionnaire and observation, are needed particularly for making generalizations and for understanding the relationships between what teachers believe and what they practise in the classroom context.
Finally, the findings of this study showed that, to a large extent, the practice of Omani physical education teachers is still based on a teacher-centred approach where the teachers play all instructional roles. This implies that curriculum planners should run workshops for training physical education teachers to shift their teaching approaches to become more student-centred. More training programmes are needed to meet the expectations for the successful implementation of physical education curricula. There is a need for training programmes which provide teachers with the skills to use different teaching styles, to apply different classroom management strategies, and to motivate and encourage students to participate in physical education lesson.

\section{References:}

Aydin, M., Baki, A., Yildiz, C. \& Kogoce, D. (2010). Mathematics teacher educators' beliefs about teacher role. Procedia Social and Behavioral Sciences, 2, 5468-5473.

Brickhouse, N. W. (1993). What counts as successful instruction? An account of a teacheself-assessment. Science Education, 77, 115-129.

Cakmak, M. (2010). An examination of concept maps created by prospective teachers on teacher roles. Procedia Social and Behavioral Sciences, 2, 24642468

Calderhead, J., \& Robson, M. (1991). Images of Teaching: student teachers early conceptions of classroom practice. Teaching and Teacher Education, 7(1), 1-8.

Capel, S. (2004). Teachers, teaching and pedagogy in physical education. In K. Green, \& K Hardman (Eds.), Physical education: Essential issues (pp.111-117). London: Sage Publications.
Connelly, F. M., \& Clandinin, D.J. (1988). Teachers as curriculum planners; Narratives of experience. New York: Teachers College Press and the Ontario Institute for Studies in Education

Creswell, J. W. (1994). Research design: qualitative and quantitative approaches. London: Sage Publications.

Crotty, M. (2003). The foundation of social research. London: SAGE.

Dey, I. (1993). Qualitative data analysis: A user friendly guide for social scientists. London: Routledge.

Doolittle, S.A., Dodds, P., \& Placek, J.H. (1993). Persistence of beliefs about teaching during formal training of pre-service teachers. Journal of Teaching in Physical Education, 12(4), 355-365.

Fang, Z. (1996). A review of research on teacher beliefs and practices. Educational Research, 38 (1), 47-64. 
Flick, U. (2006). An introduction to qualitative research (3rd edn.). London: Sage Publications.

Fung, L., \& Chow, L.P.Y. (2002). Congruence of student teachers' pedagogical images and actual classroom practices. Educational Research, 44 (3), 313-321.

Johnson, K. (1994). The emerging beliefs and instructional practices of preservice English as second language teachers. Teaching and Teacher Education. 10 (4), 439-452.

Irez, S. (2007). Reflection-oriented qualitative approach in beliefs research. Eurasia Journal of Mathematic, Science $\mathcal{E}$ Technology Education, 3 (1), 17-27.

Kagan, D. M. (1992) Implications of research on teacher belief. Educational Psychologist, 27(1), 65-90

Liamputtong, P. \& Ezzy, D. (2006). Qualitative research methods. (2nd ed.). Oxford.Marshall. C. \& Rossman. G.B. (2006). Designing Qualitative Research. (4th edn.) Thousand Oaks, CA: Sage

Matanin, M., \& Collier, C. (2003). Longitudinal analysis of pre-service teachers' beliefs about teaching physical education. Journal of Teaching in Physical Education, 22, 153-168

Merriam, S. B. (1998). Qualitative research and case study applications in education. San Francisco: Jossey-Bass

Ministry of Education. (2006). Statistical book. Muscat. Oman.

Nathmi, K. (2005). The philosophy and objectives of physical education in Oman. Risalat Al Tarbia, 8, 18-23.

Nespor, J. (1987) The role of beliefs in the practice of teaching. Journal of Curriculum Studies, 19 (4), 317-328

O'Sullivan, M. (2003).Learning to teach physical education. In S. Silverman \&
C. Ennis.(Eds.) Student learning in physical education: applying research to enhance instruction (2nd Ed.) (pp. 275294). Champiagn, IL: Human Kinetics

Peterson, T., Postholm, B., Flem, A. \& Gudmundsdottir, S. (2004). The classroom as a stage and the teacher's role. Teaching and Teacher Education, 20, 589-605.

Pajares, F. (1992). Teachers' beliefs and educational research: Cleaning up a messy construct. Review of Educational Research, 62(3), 307-332.

Randor, H. (2001). Researching your professional practice: Doing interpretive research. Buckingham: Open University Press.

Raudensky, J., O'Sullivan, M., \& O'Bryant, C.P. (2000). Socialization of prospective physical education teachers: The story of new blood. Sport, Education and Society , 5(2), 177193

Richardson, V. (1996). The role of attitudes and beliefs in learning to teach. In L., Sikula T.J., Buttery. \& E. Guyton (Eds.), Handbook of Research on Teacher Education, (2nd edn.)(pp.19-102) New York: Macmillan

Rovegno, I. (2003). Teachers' knowledge construction. In S. Silverman \& C. Ennis (Eds). Student learning in physical education: applying research to enhance instruction ( $2^{\mathrm{n}}$ ed) (pp.259310). Champaign, IL: Human Kinetics

Simmons, P., Emory, A., Carter, T., Coker, T., \& Finnegan, B. (1999). Beginning teacher: beliefs and classroom actions. Journal of Research in Science Teaching, 36, 40-930.

Strauss, A., \& Corbin, J. (1998). Grounded theory methodology. In N. K. Denzin. \& Y. S. Lincoln (Eds.), Strategies of qualitative inquiry (pp.158-183). London: Sage Publications. 
Tsangaridou, N. (2006). Teachers' beliefs. In D. Kirk., D. Macdonald \& M. O'Sullivan (Eds.), The handbook of physical education (pp.486-501). London: Sage Publications.

Vulliamy,G., (1990). The Potential of Qualitative Educational Research
Strategies in Developing18Countries. In: Vulliamy,Graham, K.M. Lewis and D.Stephens, 1990: Doing Educational Research in Developing Countries: Qualitative Strategies. London: The Falmer ss. pp.7-25. 